\title{
HOMENAGeM AOS 90 ANOS De NASCIMENTO DO ARQ $U$ IT JOÃO BATISTA VILANOVA ARTIGAS
}

$\frac{\text { OIO }}{\text { ì }}$

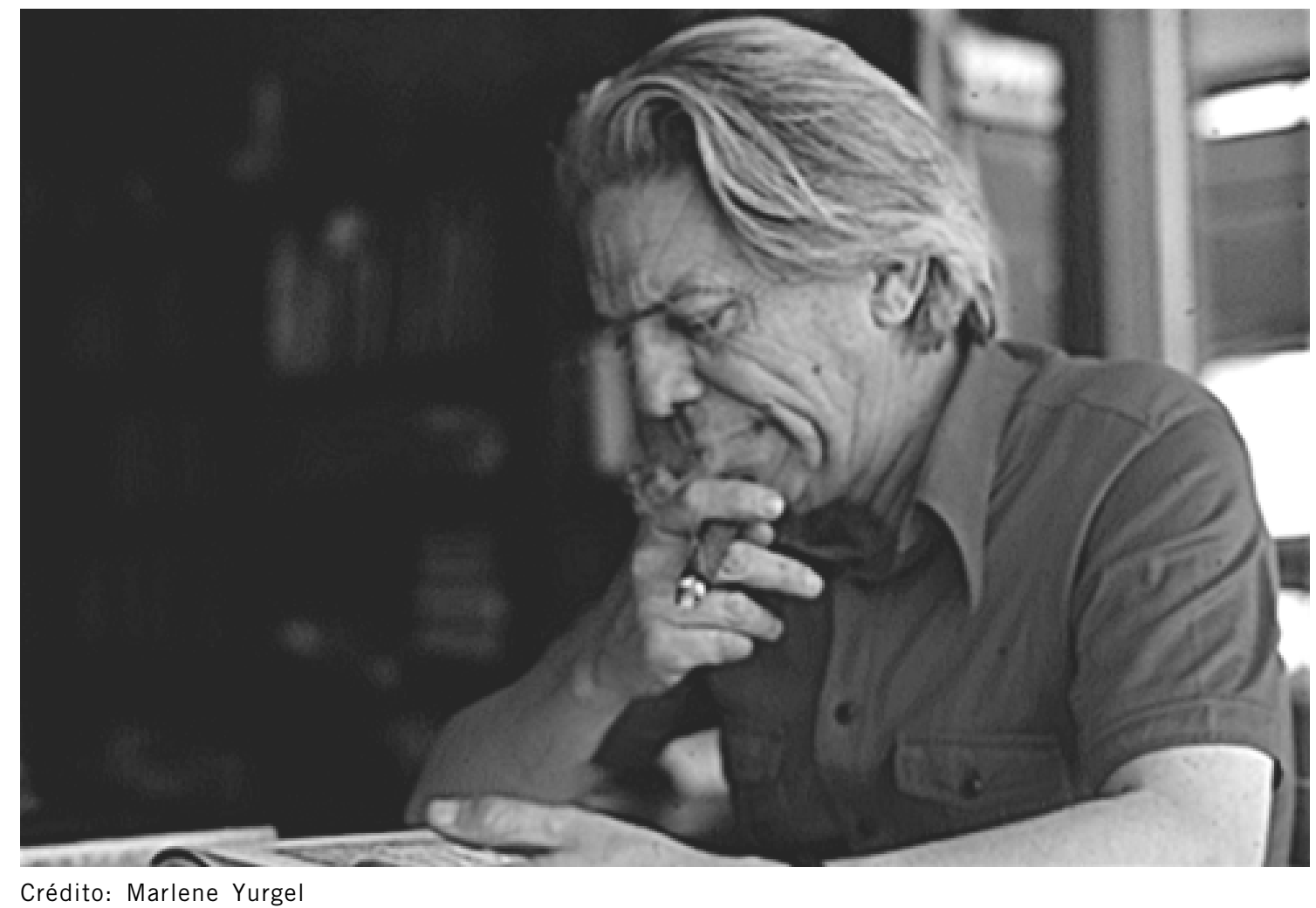

